\title{
Migrations and Ethnocultural Processes in Central Asia (Eneolithic and Bronze Age)
}

\author{
Utkir I. Abdullaeva, Anatoliy S. Sagdullaev ${ }^{b}$ \\ and Jasur E. Togaev*b \\ ${ }^{a}$ Urganch State University \\ Urganch, Uzbekistan \\ ${ }^{b}$ National University of Uzbekistan \\ Tashkent, Uzbekistan
}

Received 18.11.2019, received in revised form 01.05.2021, accepted 06.07.2021

\begin{abstract}
The ancient history of Central Asia features migrations, assimilation processes and cultural interactions between different tribes. This article elaborates on migrations and ethnocultural processes in Central Asia in the middle of the Eneolithic and Bronze Ages. Analysing the archaeological artefacts connected with ancient cultures of Central Asia is essential to reconstruct the migration and ethnocultural processes. Therefore, the main attention is drawn to the reasons and results of migrations and ethnocultural development in Central Asia. The methods applied include reviewing historical sources, historical and comparative analysis, chronological method, analysis of approaches and scientific views on the research topic.
\end{abstract}

Keywords: Eneolithic Age, Bronze Age, migration, ethnoculture, archaeological monuments, Iran, Central Asia, Indian oasis, Sarazm, Elam, Bactria, Margiana, Khorezm, Andronovo tribes, assimilation processes.

Research area: archaeology, ethnology, history, culture.

Citation: Abdullaev, U.I., Sagdullaev, A.S., Togaev, J.E. (2021). Migrations and ethnocultural processes in Central Asia (Eneolithic and Bronze Age). J. Sib. Fed. Univ. Humanit. Soc. Sci., 14(8), 1182-1190. DOI: $10.17516 / 1997-1370-0788$

\footnotetext{
(C) Siberian Federal University. All rights reserved

* Corresponding author E-mail address: utkir112@mail.ru, a.sagdullaev@nuu.uz, jasur.togaev@nuu.uz ORCID: 0000-0002-0604-3744 (Sagdullaev); 0000-0002-8202-078X (Togaev)
} 


\title{
Миграции и этнокультурные процессы в Центральной Азии (Энеолит и бронзовый век)
}

\author{
У.И.Абдуллаев ${ }^{a}$,А.С. Сагдуллаев ${ }^{6}$, Д.Э. Тогаев \\ ${ }^{a}$ Ургенчский государственный университет \\ Узбекистан, Ургенч \\ ${ }^{6}$ Национальный университет Узбекистана \\ Узбекистан, Ташкент
}

\begin{abstract}
Аннотация. Древняя история Центральной Азии характеризовалась наличием миграций, ассимиляционных процессов и культурных взаимодействий между различными племенами. В этой статье идет речь о миграциях и этнокультурных процессах, произошедших в середине энеолита и бронзового века в Центральной Азии. Для анализа археологических артефактов, связанных с древними культурами Центральной Азии, важно восстановить миграционные и этнокультурные процессы. Основное внимание обращено на причины и результаты миграций и этнокультур в Центральной Азии. В этом исследовании использовались методы обобщения исторических источников, исторический и сравнительный анализ, хронологический метод, анализ подходов и научных взглядов по теме исследования.
\end{abstract}

Ключевые слова: энеолит, бронзовый век, миграция, этнокультура, археологические памятники, Иран, Средняя Азия, Индийский оазис, Саразм, Элам, Бактрия, Маргиана, Хорезм, Андроновские племена, ассимиляционные процессы.

Научная специальность: 07.00.07 - этнография, этнология и антропология.

\section{Introduction}

Migrations of people play an important role in the history of mankind. Thus, migration as a process has a long history. In general, the anthropogenic landscape was created due to human inflow into the undeveloped countries; that means that the development of various productive forces and development of natural resources in different places is closely connected with human migration to such lands (Problemy..., 1978).

Studying ancient migrations based on archaeological monuments and cartography of the features of the spread of material culture is one of the current tasks of historical science. It is also important to identify archaeological signs of migration, their causes and pathways (Merpert, 1978). Migrations have contributed to the mixing of ethnicities and changes in the material and spiritual culture.

\section{Theoretical framework}

In different years, the issues of migrations and ethnocultural processes were studied by C.C. Lamberg-Karlovsky, R. Mc. Adams, R.H. Dyson, P. Kohl (USA, Harvard University, East Institute of Chicago university), J.C. Gardin, H.-P. Francfort, J.F. Jarrige, M.-H. Pottier (Centre of National Scientific Research, Paris), V.M. Masson, B. A. Litvinsky, V.I. Sarianidi (Archaeology Institute of Academy of Science, Russia), A. A. Askarov, E. V. Rtveladze (Academy of Science of Uzbekistan), A. I. Isakov, L.T. P'iankova (Academy of Science of Tadjikistan).

This article was written with due attention to the works of the authors mentioned above and proper analysis of their studies.

\section{Statement of the problem}

During the $20^{\text {th }}$ and early $21^{\text {st }}$ centuries, a significant contribution was made to the stud- 
ies of interactions between Sumer, Iran, Central Asia, the Indian Valley and other countries. This was reflected in articles in various scientific collections (Etnicheskie..., 1981; Drevnie..., 1986; Vzaimodeystvie..., 1987; India..., 2000; Mei, 2003). Thus, the forms of migration that took place in the Ancient East were commented as follows: 1) Attempt to directly colonising the areas of smaller cultural integration than the region where larger cultural integration exists; 2) Development of long-distance trade with the aim of mastering and controlling new resources, creating new elements of technology in social sectors (Lamberg - Karlovsky, 1986: 167).

In our view, the above description does not fully explain the essence of migrations because, besides moving from high cultural provinces, the migrations also include moving from poor areas to better developed lands.

The Bronze Age is one of the most critical stages in the history of ancient Central Asia (Rtveladze, 2005), characterised by extraordinary changes in the development of economy, social relations, material and spiritual culture. During this period, the developed territories grew bigger, forms of production economy spread to the northeastern regions of the continent, and specialised crafts boosting the development of urbanisation processes and urban culture appeared in the southern regions.

As a result of metallurgical development during the Eneolithic and Bronze Age, people learned mining copper and other metals (tin and lead). They began using precious metals such as gold and silver, as well as lapis lazuli and turquoise.

During the Eneolithic period, from about the middle of the $4^{\text {th }}$ millennium BC, the oases of the Kukcha, Kunduz, Darya Bangi and Sheravan rivers in the Amu Darya-Panj basin were gradually occupied by population groups migrating from the Baluchistan - Indian Valley (Gardin, Lyonnet, 1978).

These regions (northeast Afghanistan) formed the eastern part of ancient Bactria. There were unique minerals and metal deposits (lapis lazuli, silver, gold) in its mountainous territories (Sagdullaev, Togaev, 2018: 89). Therefore, one of the main reasons for mi- gration during this period was mining in the mountains.

During the Eneolithic and Early Bronze Age, the Sarazm settlement was founded in Zarafshan oasis $(15 \mathrm{~km}$ west of present-day Panjikent) by the tribes that migrated from highly developed cultural-economic areas (Baluchistan, Southern Turkmenistan) (Isakov, 1986 b; Isakov, 1996). At this point, it is necessary to consider the presence of minerals, copper and tin deposits in the upper and lower reaches of the Zarafshan River and in the Kyzyl-Kum (Buriakov, 2001).

Sarazm is distinctive in its unique architectural traditions: houses, temples and crafts, metal tools and utensils, jewellery and beads made of rare stones like lapis lazuli, onyx and agates (Isakov, 1986 a).

Sarazm was built in a previously uninhabited area. The groups migrating from Baluchistan and the Geoksur oasis of Southern Turkmenistan did not mix with each other at first. This is evidenced by the ceramic utensils typical of the cultures and the isolated accommodation of both groups. However, in the early Bronze Age, the material culture of Sarazm and some features of construction machinery and architecture appeared similar to those of the Bronze Age cultures in the south of Central Asia, Afghanistan and northeastern Iran (Razzakov, Kurbanov, 2004).

In general, the development of the Panj Basin and the upper Zarafshan oasis during the Eneolithic period is an exemplary step for large-scale and long-term migrations. Their reasons were determined by economic factors.

For these same reasons, in the middle of the $3^{\text {rd }}$ millennium $\mathrm{BC}$, the migration of the Harappa - Mohenjodaro civilisation representatives to the Panj Basin resulted in the emergence of such a large trade site as Shortughai (Frankfort, Pottier, 1978). It is located more than 1,100 km from Mohenjodaro, one of the centres of Indian civilisation. In this direction, the migrants crossed through the canyons and hills of the high Hindu Kush Mountains (Sagdullaev, 2000).

Since the Bronze Age, the lapis lazuli has been an extremely popular precious stone in the Ancient East, i. e. in a large territory 
surrounding Egypt, Mesopotamia, Iran, India and Central Asia. For this reason, besides the Indian Valley, the lapis lazuli mined from the Hindu Kush Mountains in the vicinity of Shortughai was distributed all around Asian countries through Iran and Elam. The formation of the «Lapis lazuli Road» created new connections in the Ancient East communication and trade (Mavlonov, 2008). They were used in the further stages of migration.

The above discussion was about the economic causes of migration. However, migration was also influenced by demographic factors, such as the need to occupy new undeveloped lands due to population growth in the Ancient East.

According to the published research papers, at the end of the $4^{\text {th }}$ millennium $\mathrm{BC}$, the rapid population growth in southern Mesopotamia - Sumer, caused the development of the Elam region of southwestern Iran, and later on, the migration of some population groups to the northeast of Iran, the territorial borders of Central Asia (Lamberg-Karlovsky, 1986: 168-170).

The next phase of migration occurred in the late $3^{\text {rd }}$ millennium - early $2^{\text {nd }}$ millennium $\mathrm{BC}$. It was widely associated with the seizure of the lower Murghab River (Margiana) and Bactria. According to V.I. Sarianidi, in the second half of the $3^{\text {rd }}$ millennium $B C$, climate warming (aridization) in the Middle East caused mass migrations. During this period, the amount of rain decreased significantly, and drought began. Under these conditions, the population had to leave their habitations (Sarianidi, 2010: 16).

Also, during the reign of King Naram$\sin (2236-2200 \mathrm{BC})$, the invasion of nomadic steppe tribes from the west into Mesopotamia boosted migrations of local people. The Akkad, Sumer and Elam tribes moved to eastern Iran and southern Turkmenistan (Sarianidi, 2010: 17-18). More than 100 settlements, identified on the lands of Margiana and representing Bronze Age archaeological sites, showed a great migration flow. The migrants did not only flee to the Murghab oasis. They entered the neighbouring Bactrian territories with their property and livestock. In archaeology, the culture formed in Margiana and Bactria is called
Gonur, Dashtli-Sapalli (Ceramic) Culture or Ox civilisation.

Consequently, the Margiana and Bactrian regions were developed as a result of migration from more advanced centres of Eastern civilisation. The migrants from these civilisations were peasants, livestock breeders, craftsmen and builders who knew the art of architecture and urban planning, defence, construction of houses and large buildings. They represented a more progressive, organised society formed in the system of state and governance in their country (Sagdullaev, Togaev, 2018: 90). This is evidenced by the large palaces, temples and economic complexes found in Margiana and Bactria (Sarianidi, 2008; Huff, Shaydullaev, 1999). In an attempt to preserve their native material and spiritual culture, the foreigners expanded the territorial range of certain civilisations in the East. This type of migration is well-known in the archaeology of the Margiana-Bactrian period (Kuz'mina, 1981).

\section{Methods}

This article uses methods and principles such as comparing, summarising historical data, comparative analysis of scientific views and concepts, the principle of objectivity, and a chronological approach. Besides that, the archaeological artefacts make it possible to reconstruct migration directions, causes and consequences of the ethnocultural processes in ancient Central Asia.

\section{Discussion}

During the Eneolithic and Bronze Ages, artificial irrigation-based agriculture was well developed on the slopes of Capet Mountain in southwestern Turkmenistan. Large archaeological sites, such as Namazgah and Altintepa, were called the «peasants' capitals» or «cities of the Altintepa civilisation», and some economic and cultural ties of this civilisation with Mesopotamia and the ancient Indian Harappa civilisation were found (Masson, 1966; Masson, 1981).

By the end of the $3^{\text {rd }}$ millennium $B C$, these large centres were gradually falling apart. V.M. Masson wrote that the locals began to leave their homes and move to the low- 
er Murghab oasis in the east of the city with all their property, household items and cattle (Masson, 1981). The main reasons for the migration were limited access to irrigation agriculture, cultivation of surrounding fields for 2500 years, soil salinisation and climate warming (Masson, 1981).

It is clear that the tribes that came from faraway lands were not the only ones to contribute to the civilisation of Margiana and Bactrian; people from the surrounding areas also took part in it. Therefore, the researchers compared the main aspects of architecture, crafts and material culture of the Altintepa and Ox civilisations. As a result, they discovered similarities in the monumental architecture, construction of large temples and houses, the availability of wide streets for carts and common traits in ceramics, metalwork, stonework (Bokiev, Shaydullaev, Iuldosheva, 2015: 78-79).

However, the fine arts and general literal culture, the architecture and construction techniques of the Margiana-Bactrian civilisation of the Bronze Age were unique. For example, the construction principles of the Gonur and Dashtli-Sapalli civilisations were based on precise geometric shapes such as rectangles and circles. Rectangular and circular zodiacs were found on the defensive walls (Mamedov, 2003: 116-117).

The cultural impact of the main centres of the Ancient Oriental civilisation was discovered on stone, ceramic and bronze images of the Margiana-Bactrian seals, amulets (dragon, snakes, birds, mythological scenery), sculptures, and the descriptions on gold-silver painted dishes (Sarianidi, 1986; Sarianidi, 1999; Shaydullaev, 2018: 6-7). In our view, such close parallels in the material and spiritual monuments indicate the presence of the population of the Margiana-Bactrian civilisation with a high level of advanced cultural development. In addition to this, it should be noted that the migrants who came to the oases of the lower Murghab and Amu Darya rivers managed to use the wild steppe and fertile lands for farming. Supposedly, they did not find any competitors in the new countries. However, newcomers surrounded their houses, palaces and temples on the still unknown land with defensive walls.
In this regard, they used their previous knowledge, skills and construction experience.

According to the published research papers, representatives of the Gonur and DashtliSapalli cultures were not satisfied with the first cultivated oases and districts. They continued moving towards Kughitang, Baysun and the mountainous areas of southern Tajikistan and to Zarafshan oasis (Sagdullaev, Togaev, 2018: 90; Stancho, Shaydullaev, 2018; Sarianidi, 1979; Askarov, 1981). They also took their way from Zarafshan oasis to East Fergana, and according to some assumptions, reached eastern Turkestan (Sarianidi, 2010).

In the middle and the second half of the $2^{\text {nd }}$ millennium BC, the steppe livestock breeders and tribes of the Andronovo culture from the southern Ural and Central Kazakhstan steppes actively participated in the common Central Asian migration processes together with the southern agricultural peoples.

The distribution of the steppe tribes in Central Asia and the location of their artefacts are described in papers published in different periods (Guliamov, Islamov, Askarov, 1966; Sredniaia Aziia ... 1966). It was also suggested to designate these monuments as belonging to Andronovo, a clear historical and cultural unit, classifying them into separate regional variants, such as Zarafshan, Fergana, Tien ShanYettisuv and Tashkent oasis (Dzhurakulov, Avanesova, 1983: 47). However, some steppe tribes were also found along the Uzbek coast and southwest of Turkmenistan, in the lower Murghab oasis and on the shores of Kalif Uzbay, in the Surkhan oasis, southern Tajikistan and northern Afghanistan (Litvinskiy, Solovev, 1972; Sarianidi, 1975; Rakhmanov, Shaydullaev, 1985). Today, the thirty monuments peculiar to the culture of livestock breeders of the Bronze Age identified in the Zarafshan oasis are combined with the Zarafshan version of the Andronovo historical-cultural unit (Avanesova, 2016).

According to E.E. Kuz'mina, the migration of the livestock breeder tribes to Central Asia was a gradual process that occurred, perhaps, in the $16^{\text {th }}$ century BC. Its starting points are in the steppes of the Volga, South Ural, northeast of Kazakhstan and West Si- 
beria. After that, the livestock breeding tribes were found in the Southern Aral Sea, the eastern Caspian, southwestern Turkmenistan, the Lower Murghab, Zarafshan and Tashkent oasis, Fergana Valley and Southern Tajikistan (Kuz'mina, 1964).

The location of the artefacts created by the steppe livestock breeder tribes on the slopes of the Tien Shan, the Pamir Mountains and oases of large rivers (Panj, Vakhsh, Amu Darya, Zarafshan, Narin) proves the fact that migrations were a universal process (Vinogradova, Kuz'mina, 1986: 128). One of the reasons for the steppe tribes to move from the north to the south was the rapid development of livestock, growth of herds and the need for new pastures and water-rich areas (Vinogradova, Kuz'mina, 1986: 148). Another factor was the mining development in the Bronze Age, natural metals such as gold, silver, lapis lazuli and turquoise, as well as copper, lead and tin deposits in Central Kazakhstan. The sale of raw materials, metal and lapis lazuli, was an essential part of the economic relations between the tribes (Avanesova, 1987).

According to researchers, in the second half of the $2^{\text {nd }}$ millennium $\mathrm{BC}$, the tribes of southern Central Asia did not settle in the northern regions or have a significant impact on the cultural development of steppe tribes since their livelihoods and farming practices bounded them to the oasis (Vinogradova, Kuz'mina, 1986). However, this conclusion does not correspond to historical facts, as the migration of settled farmers from the south to the north and east and their location in river valleys and foothills are evidenced by the Bronze utensils and ceramic dishes peculiar to Dashtli-Sapalli culture found in the monuments of the Zarafshan oasis and Eastern Fergana (Avanesova, 1992). Therefore, migrations were carried out independently of each other from south to north and from north to south.

In some areas, farmer tribes adapted to the natural conditions and engaged in livestock breeding and mining. The highland pastures in the south of Tajikistan and the Zarafshan oasis made it possible to breed smaller livestock (P'iankova, 1989; Vinogradova, Giotselt, P'iankova, 2003). The steppe tribes that migrated from the north lived next to them. The relationship was peaceful, probably because the southern and northern tribes were not competitive due to economic ties and aspiration for exchanges. For example, ceramic dishes peculiar to the Dashtli-Sapalli and Andronovo cultures were found in the Tukayli settlement in the Middle Zarafshan oasis and in the Kyzylsu oasis in southern Tajikistan (Avanesova, 1992; Vinogradova, Giotselt, P'iankova, 2003).

Regionally, representatives of these cultures were at first located separately. However, it can be concluded that regional neighbourhood and mutual economic relations influenced the lifestyle and traditions of different tribes for a long period.

Researchers usually illustrate the migration process with a distribution of a new culture, language, and ethnicity. Considering the primary regional centers of migration to Central Asia (Front Asia, Elam, the Indian oasis), it is possible to hypothesise the spread of different languages (Hurrite, Elam, Dravid) in the region, as the Andronovo culture steppe livestock breeders are associated with Iranianspeaking tribes. European orientalists first proposed this issue in the $19^{\text {th }}$ century (Litvinskiy, 1981). However, it is known that the Andronovo tribes were likely to be Turkic-speaking. But it is not our task to shed light on such controversies.

As far as the ethnocultural issues are concerned, the study of the problems of formation, ethnic geography and cartography of historical and cultural regions in Central Asia is of particular importance. It is important to identify the diversity of socio-economic, cultural and ethnic processes (Sagdullaev, 2018).

\section{Conclusion / Results}

Thus, migration to Central Asia during the Eneolithic and Early Bronze ages can be divided into the following stages:

1) The $4^{\text {th }}$ millennium and the middle of the $3^{\text {rd }}$ millennium BC. Development of the left oases of the Panj River basin. The primary centre of migration is Baluchistan, Indian Valley.

2) The second half of the $4^{\text {th }}$ millennium BC. Development of the Upper Zarafshan oa- 
sis. The initial settlement is Baluchistan, South Turkmenistan.

3) The middle of the $3^{\text {rd }}$ millennium $\mathrm{BC}$. Migration to the left coast of the Panj Basin. The region of its origin is the Indian Valley, the Harappa civilisation.

4) The end of the $3^{\text {rd }}$ millennium - the beginning of the $2^{\text {nd }}$ millennium. The development of the Margiana and Bactrian oases. The first regions in which migration began are Front Asia, the territories between the two rivers, southwest and northeast of Iran, southwest of Turkmenistan.
Based on these data, one can conclude that in the history of Central Asia, external migration played an essential role in the emergence of new cultures and civilisations. Therefore, researchers have described migration as a factor in the development of civilisations.

In this regard, the peculiarities of historical and cultural development in different geographical conditions caused by the migration of ancient cultures, as well as the key features of economic and cultural types in Central Asia, are of great importance.

\section{References}

Askarov, A.A. (1981). K peredatirovke kul'tury Zamanbaba [To redating of Zamanbaba culture]. In: Kul'tura i iskusstvo drevnego Khorezma [Culture and art of ancient Khorezm]. Moscow, Nauka, 107-108 p.

Avanesova, N.A. (1987). Stepi Severa i oazisy Iuga: problema kul'turnykh vzaimodeistviy v epokhi bronzy [Steppes of the North and South oases: problem of cultural interactions during the Bronze Age]. In: Vzaimodeistvie kochevykh kul'tur i drevnikh tsivilizatsiy [Interaction of nomadic cultures and ancient civilisations]. Alma-Ata, 53-55 p.

Avanesova, N.A. (1992). Rannie Andronovskie kompleksy Sredney Azii [Early Andronovo complexes of Central Asia]. In: Paleoekologiia i problemy pervobytnoy arkheologii Tsentralnoy Azii [Paleoecology and problems of primitive archeology of Central Asia]. Samarkand, 51-53 p.

Avanesova, N.A. (2016). Zarafshanskiy variant Andronovskoy istoriko-kulturnoy obshchnosti [Zarafshan variant of the Andronovo historical and cultural generality]. In: Arkheologiia Uzbekistana $v$ gody nezavisimosti: dostizheniia i perspektivy [Archaeology of Uzbekistan in the Independence years: achievements and prospects]. Samarkand, 34-37 p.

Bokiev, A., Shaydullaev, A., Iuldosheva, Z. (2015). Oks tsivilizatsiyasi [Oxus civilisation]. Tashkent, $176 \mathrm{p}$.

Buriakov, Iu.F. (2001). Sostoianie metallurgicheskogo proizvodstva v period vozniknovenia Avesti [Condition metallurgical manufacture during the emergence of Avesto], In: O'zbekiston tarikhi [History of Uzbekistan]. 1, Tashkent, 17-21 p.

Drevnie tsivilizatsii Vostoka (1986) [Ancient civilisations of the East]. Edited by V. M. Masson. Tashkent, Fan, 226 p.

Dzhurakulov, M.D., Avanesova, N.A. (1983). Istoriografiia epokhi bronzy Sredney Azii [Historiography of the Bronze Age in Central Asia]. Samarkand, $70 \mathrm{p}$.

Etnicheskie problemy istorii Tsentral'noy Azii v drevnosti (2oe tysiacheletie do n. e.) (1981) [Ethnic problems of the history of Central Asia in antiquity (the $2^{\text {nd }}$ millennium BC)], Moscow, Nauka, $369 \mathrm{p}$.

Frankfort, H.-P., Pottier, M.-H. (1978). Preliminary Survey on the Protohistoric Settlement Shortughai haarrappian [Sondage préminaire sur L'etablissement proto historique harappéen de Shortughai]. In: Arts Asiatiques, 34. 29-86.

Gardin, J.-C., Lyonnet, B. (1978). Archaeological research in Eastern Bactria (1974-1978): first results [La prospection arxéologique de la Bactriane orientale (1974-1978): premiers résultats], Mesopotamia, 13-14, 99-154 p.

Guliamov, Ia., Islamov, U., Askarov, A. (1966). Pervobytnaia kul'tura i vozniknovenie oroshaemogo zemledeliia v nizov'iakh Zarafshana [Primitive culture and emergence of irrigated agriculture in the lower reaches of Zarafshan]. Tashkent, Fan, 215-219 p. fig. 56. 
Huff, D., Shaydullaev, Sh. (1999). Nekotorye rezul'taty rabot uzbeksko-germanskoy ekspeditsii na gorodishche Dzharkutan [Some results of works of the Uzbek-German expedition on the site of ancient settlement Jarkutan]. In: IMKU, 30. Samarkand. 19-26 p.

India and Central Asia (Pre-Islamic period) (2000). Tashkent, 288 p.

Isakov, A.I. (1986 a). Sarazm. Gorizonty drevney tsivilizatsii [Sarazm. Horizons of the ancient civilisation], In: Nauka i zhizn' [Science and life]. Moscow. 78-81 p.

Isakov, A.I. (1986 b). Sarazm: novyy rannezemledel'cheskiy pamiatnik Sredney Azii [Sarazm: new early agricultural monument of Central Asia], In: Sovetskaia arkheologiia [Soviet archaeology]. 1. 152-157 p.

Isakov, A.I. (1996). Sarazm: agricultural centre of ancient Sogdiana, In: Bulletin of the Asia Institute. 8. $1-12 \mathrm{p}$.

Kuz'mina, E.E. (1964). O iuzhnykh predelakh rasprostraneniia stepnykh kul'tur epokhi bronzy $v$ Sredney Azii [About southern limits of distribution of the steppe cultures of the Bronze Age in Central Asia]. In: Pamiatniki kamennogo i bronzovogo veka Evrazii [Monuments of the Stone and Bronze Ages of Eurasia]. Moscow, Nauka, 121-140 p.

Kuz'mina, E.E. (1981). Proiskhozhdenie indoirantsev $v$ svete noveyshikh arkheologicheskikh dannykh [Origin of Indo-Iranians in the light of the newest archaeological data]. In: Etnicheskie problemy istorii Tsentral'noy Azii v drevnosti [Ethnic problems of the history of Central Asia in antiquity]. Moscow, Nauka, 103 p.

Lamberg-Karlovsky, C.C. (1986). Kontury drevneyshey istorii Iranskogo plato [Contours of the ancient history of the Iranian plateau], In: Drevnie tsivilizatsii Vostoka [Ancient civilisations of the East]. Tashkent, Fan, 167-170 p.

Litvinskiy, B.A. (1981). Problemy etnicheskoy istorii Sredney Azii vo II tysiacheletii do n. e. (Sredneaziatskiy aspekt ariiskoy problemy) [Problems of ethnic history of Central Asia in the $2^{\text {nd }}$ millenium BC (the Central Asian aspect of an Aryan problem)]. In: Etnicheskie problemy istorii Tsentralnoy Azii v drevnosti [Ethnic problems of the history of Central Asia in antiquity]. Moscow, Nauka, $154 \mathrm{p}$.

Litvinskiy, B.A., Solov'ev V.S. (1972). Stoianka stepnoy bronzy v Iuzhnom Tadzhikistane [Parking of steppe bronze in Southern Tajikistan]. In: Uspekhi sredneaziatskoy arkheologii [Successes of the Central Asian archaeology]. Leningrad, Nauka, 41-47 p.

Mamedov, M. (2003). Drevniaia arkhitektura Baktrii i Margiany [Ancient architecture of Bactria and Margiana]. Ashgabat, $140 \mathrm{p}$.

Masson, V.M. (1966). Rassvet i upadok zemledel'tsev iugo-zapada [Blossom and decline of farmers of the southwest]. In: Sredniaia Aziia v epokhu kamnia i bronzy [Central Asia during the Stone and Bronze Ages]. Moscow, Leningrad, Nauka, 151-156 p.

Masson, V.M. (1981). Altyn-depe [Altintepa]. In: Trudy YuTAKE, V. 18. Leningrad Nauka, 129-130 p.

Mavlonov, U. (2008). Ancient roads of Central Asia. Tashkent, Akademia, 56-57 p.

Mei, J. (2003). Cultural Interaction between China and Central Asia during the Bronze Age, Proceedings of British Academy. London, 1-39 p.

Merpert, N. Ia. (1978). Migratsii v epokhu neolita i eneolita [Migrations during the Neolithic and Eneolithic Ages], In: Sovetskaia arkheologiia [Soviet archaeology], 3. 9-27 p.

Problemy etnicheskoy geografii i kartografii (1978) [Problems of ethnical geography and cartography] Edited by S.I. Bruk. Moscow, Nauka, 86 p.

Piankova, L.T. (1989). Drevnie skotovody Iuzhnogo Tadzhikistana [Ancient cattlemen of Southern Tajikistan]. Dushanbe, Donish, 133 p.

Rakhmanov, U.V., Shaydullaev, Sh.B. (1985). O vliianii kul'tur stepnoy bronzy na keramicheskie kompleksy Sapallinskoy kultury [About the influence of cultures of steppe bronze on ceramic complexes of Sapalli culture]. In: Obshchestvennye nauki v Uzbekistane, 11 [Social sciences in Uzbekistan]. Tashkent, $58-63 \mathrm{p}$.

Razzakov, A., Kurbanov, Sh. (2004). Isledovaniia Sarazmskogo otriada v 2003 g. [Researches of the Sarazm group in 2003], In: Archaeological works in Tajikistan. 29. Dushanbe, 174-192 p.

Rtveladze, E.V. (2005). Tsivilizatsii, gosudarstva, kul'tury Tsentralnoy Azii [Civilisations, states, cultures of Central Asia]. Tashkent, 2005. 288 p. 
Sagdullaev, A.S. (2000). Central Asia and India: formation and development of early historical and cultural relations, In: India and Central Asia (Pre-Islamic period). Tashkent, 119-120 p.

Sagdullaev, A.S. (2018). Aktual'nye problemy drevney istorii Tsentralnoi Azii [Actual problems of the ancient history of Central Asia]. In: Formirovanie istoriko-kul'turnykh oblastey v Tsentralnoy Azii i problemy etnicheskoy geografii [Formation of historical and cultural areas in Central Asia and problems of ethnic geography]. Tashkent, $8 \mathrm{p}$.

Sagdullaev, A.S., Togaev, J.E. (2018). Migratsii epokhi bronzy v Tsentral'noy Azii [Migrations of the Bronze Age in Central Asia], In: Problemy istorii, arkheologii i etnologii Tsentral'noy Azii [Problems of history, archaeology and ethnology of Central Asia]. Tashkent, 88-94 p.

Sarianidi, V.I. (1975) Stepnye plemena epokhi bronzy v Margiane [Steppe tribes of the Bronze Age in Margiana]. In: Sovetskaia arkheologia, 2. Moscow, P. 20-28 p.

Sarianidi, V.I. (1979). K voprosu o kul'ture Zamanbaba [On Zamanbaba culture]. In: Etnografiia i arkheologiia Sredney Azii [Ethnography and archeology of Central Asia]. Moscow, Nauka, 23-28 p.

Sarianidi, V.I. (1986). Zmei i drakony v gliptike Baktrii i Margiany [Snakes and dragons in the glyptic of Bactria and Margiana]. In: Vostochnyy Turkestan i Sredniaia Aziia v sisteme kul'tur drevnego i srednevekovogo Vostoka [East Turkestan and Central Asia in the system of cultures of the ancient and medieval East]. Moscow, Nauka, 66-71 p.

Sarianidi, V.I. (1999). Siro-khettskoe poiskhozhdenie Baktriisko-margianskoy gliptiki [Siro-Hetts appearance of Baktrian-Margian glyptic]. In: Vestnik drevnei istorii, 1 [Journal of ancient history]. Moscow, $53-73 \mathrm{p}$.

Sarianidi, V.I. (2008). Arkheologicheskie dokazatel'stva protozoroastrizma v Baktrii i Margiane [Archaeological proofs of protozoroastrism in Bactria and Margiana], In: Trudy Margianskoy arkheologicheskoy ekspeditsii [Margian archaeological expedition]. Moscow, 9-27 p.

Sarianidi, V.I. (2010). Zadolgo do Zaratushtry [Long before Zaratushtra]. Moscow.

Shaydullaev, A. Sh. (2018). Glyptics and sphragistics of Sapalli culture. Abstract of PhD dissertation. Tashkent, Institute of Archeology of the Academy of Sciences of Uzbekistan Republic, 2018. 42 p.

Sredniaia Aziia v epokhu kamnia i bronzy [Central Asia during the Stone and Bronze Ages] (1966). Moscow, Leningrad, Nauka, 213-220 p.

Stancho, L., Shaydullaev, Sh. (2018). Nekotorye rezul'taty arkheologicheskikh issledovaniy v predgoriakh Kugitanga v 2016 i 2017 godakh [Some results of archaeological researches in the foothills Kugitang in 2016 and 2017]. In: Tezisy dokladov mezhdunarodnoy nauchnoy konferentsii «Formirovanie istorikokulturnykh oblastey $v$ Tsentralnoy Azii i problemi etnicheskoy geografii» [Theses of reports of the international scientific conference «Formation of historical and cultural areas in Central Asia and problems of ethnic geography»]. Tashkent, 2018. 13-14 p.

Vinogradova, N.M., Giotselt, T., P'iankova, L.T. (2003). Arkheologicheskaia razvedka v basseyne reki Kyzylsu (Iuzhnyy Tadzhikistan) [Archaeological investigation in the river basin Kyzylsu (Southern Tajikistan)]. In: Rossiiskaia arkheologiia, 1 [Russian archaeology]. Moscow, 103-116 p.

Vinogradova, N.M., Kuz’mina, E.E. (1986). Kontakty zemledelcheskikh i stepnykh plemen v epokhu bronzy [Contacts of agricultural and steppe tribes during the Bronze Age]. In: Vostochnyy Turkestan i Sredniaia Aziia v sisteme kul'tur drevnego i srednevekovogo Vostoka [East Turkestan and Central Asia in the system of cultures of the ancient and medieval East]. Moscow, Nauka, 128-148 p.

Vzaimodeystvie kochevykh kul'tur i drevnikh tsivilizatsiy (1987) [Interaction of nomadic cultures and ancient civilisations]. Almaty, Nauka, $210 \mathrm{p}$. 